Deborah K. Rasch MD, Dawn E. Webster MD, Trevor G. Pollard MD, Mary Ann Gurkowski MD

\title{
Lumbar and thoracic epidural analgesia via the caudal approach for postoperative pain relief in infants and children
}

Thirty infants scheduled for a variety of gastrointestinal, genitourinary and thoracic surgical procedures were selected for insertion of lumbar or thoracic epidural catheters via the caudal approach using either an Intracath ${ }^{\circledast}$ or a Burron ${ }^{\otimes}$ continuous brachial plexus kit. The catheters were inserted with ease by residents in training and no catheter-related complications were encountered. Lidocaine 0.5 per cent with 1:200,000 epinephrine was then injected to assure proper placement of the catheter before nurcotics were administered. Postoperative analgesia was adequate in all patients using preservative-free morphine $0.05 \mathrm{mg} \cdot \mathrm{kg}^{-1}$. The mean dosing interval was $15 \mathrm{hr}$ and no episodes of nausea, vomiting, hypotension or histamine release were noted. Urinary retention occurred in two infants and one infant became apnocic three hours after epidural morphine administration but responded to naloxone and pulmonary ventilation with bag and mask. In conclusion, epidural catheters placed via the caudal approach are a safe and effective means of providing postoperative pain control in infants using preservative-free morphine. However, the use of epidural narcotics in infants less than two years of age is restricted to those who will receive intensive care unit monitoring postoperatively so that if apnoea occurs, rapid intervention can be taken by skilled nursing personnel.

\section{Key words}

ANAESTHESIA: paediatric;

ANAESTHETIC TECHNIQUES: epidural, caudal; ANALGESIA: postoperative.

From the Department of Anesthesiology, University of Texas Health Science Center, San Antonio, Texas.

Address correspondence to: Dr. D. K. Rasch, UTHSC at San Antonio, Dept. of Anesthesiology, 7703 Floyd Curl Dr., San Antonio, TX 78284-7838.

Original work presented at the American Academy of Pediatrics Section on Anesthesiology, March 1989.
Trente enfants cédulés pour une variété de chirurgies thoraciques gastrointestinales ou génito-urinaires ont été choisis pour l'insertion de cathéters épiduraux, lombaires ou thoraciques par voie caudale utilisant soit l'Intracath ${ }^{\text {B }}$ ou un kit pour bloc continu du plexus brachial Burron ${ }^{\$}$. Les cathéters ont été insérés facilement par des résidents en entrainment et aucune complication reliée au cathéter fut notée. De la lidocaine 0,5 pour cent avec 1:200,000 d'épinéphrine était injectée afin d'assurer un bon positionnement du cathéter avant l'administration des narcotiques. L'analgésie postopératoire fut adéquate chez tous les patients utilisant de la morphine $0,05 \mathrm{mg}$. $\mathrm{kg}^{-1}$ sans préservatif. L'intervalle moyen pour ces doses était de 15 heures et aucune épisode de nausée, vomissement, hypotension ou histamino libération ne fut noté. La rétention urinaire et survenue chez deux enfants alors qu'un autre est devenu apnéique trois heures après l'administration de morphine épidurale mais a répondu au naloxane et à la ventilation au masque. En conclusion, des cathéters épiduraux placés par voie caudale sont sécuritaires et efficaces pour soulager la douleur postopératoire chez les enfants lorsqu'on ufilise la morphine sans aucun préservatif. Cependant, l'utilisation de narcotiques par voie épidurale chez les enfants âgés de moins de deux ans est réservée strictement à ceux qui doivent recevoir une surveillance postopératoire intensive afin d'intervenir rapidement en cas d'apnée.

Caudal and lumbar epidural anaesthesia has been described in the paediatric patient for both intraoperative anaesthesia and postoperative analgesia. ${ }^{1-9}$ Techniques of epidural anaesthesia in children include single injection, intermittent bolus or continuous infusion of local anaesthetics or narcotics through a catheter inserted at a lumbar or thoracic interspace, and single injection caudal epidural anaesthesia. Continuous epidural postoperative analgesia in children younger than two years has not become popular due to the lack of equipment and techniques which would allow relatively quick and safe 


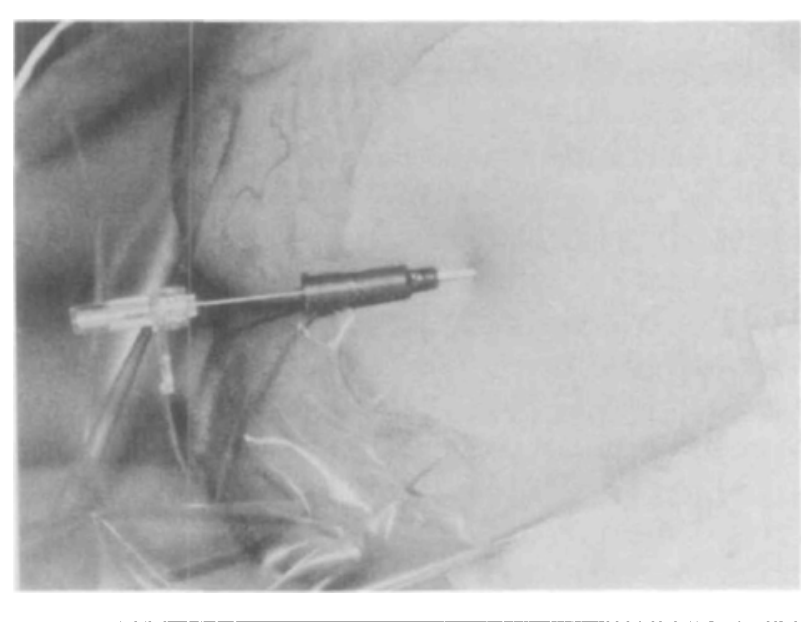

FIGURE After the caudal canal is identified by loss of resistance technique, the soft catheter is inserted over the blunt needle into the caudal epidural space.

long-term access to the epidural space. Recently Bosenberg et al. ${ }^{10}$ described the use of the caudal approach for thoracic placement of epidural catheters for intraoperative anaesthesia. We report 30 infants under two years of age in whom the caudal approach to placement of lumbar or thoracic epidural catheters was very successful for postoperative pain control using preservative-free morphine.

\section{Methods}

Patients aged two days to 18 months, weight $1.4-12 \mathrm{~kg}$, scheduled for a variety of gastrointestinal, genitourinary, and thoracic procedures were selected for placement of epidural catheters via the caudal approach. The choice of primary anaesthetic technique was determined by the individual anaesthetist and all catheters were inserted after the patients were anaesthetized. Parental informed consent was obtained the evening before surgery and only those patients admitted for postoperative care to the Paediatric or Neonatal Intensive Care Unit were considered for catheter placement.

Once anaesthetized, patients were placed in the lateral decubitus position and the sacral hiatus was identified. An 18-ga (Burron continuous brachial plexus $\mathrm{kit}^{(9)}$ ) or 20-ga introducer needle (Intracath ${ }^{\oplus}$ ) was then inserted through the sacral hiatus at an angle of $30-45^{\circ}$ from the skin. Penetration of the sacrococcygeal ligament could be felt as a slight "pop" approximately $2-3 \mathrm{~mm}$ from the skin surface in neonates, and $5-6 \mathrm{~mm}$ in the two-year-old child. Following penetration of the sacrococcygeal ligament, the soft catheter was advanced into the caudal canal over the introducer needle (Figure). The length of indwelling epidural catheter was equal to the distance between the operative site and the introducer. A 20-ga epidural catheter was used for the 18-ga introducer needle and a $22-24$ ga for the 20-ga needle. If the catheter did not thread easily, placement could be facilitated by injecting 2-3 $\mathrm{ml}$ of preservative-free sterile saline through the introducer catheter. At no time was a catheter advanced against resistance.

Lidocaine 0.5 per cent with 1:200,000 epinephrine was injected at the end of the operative procedure through the catheter to provide immediate analgesia and to determine the dermatomal distribution of effective analgesia. Takasaki's formula: $0.05 \mathrm{ml} \times \mathrm{wt}(\mathrm{kg}) \times$ number of spinal segments to be blocked, was used to calculate the total dose of local anaesthetic. " After emergence from general anaesthesia, a sensory level was documented before epidural morphine, $0.05 \mathrm{mg} \cdot \mathrm{kg}^{-1}$, was given. The catheter position was documented by postoperative radiographs. All infants were monitored with an apnoea monitor, pulse oximeter, and ECG in the Intensive Care Unit. They were also observed for hypoventilation, apnoea, bradycardia, hypotension or CNS depression. Criteria for reinjection were: an inconsolable infant after other comfort measures had failed, heart rate or blood pressure 15 per cent above baseline after other reasons (hypoventilation, full bladder) had been eliminated, and grimace or crying to gentle palpation near the operative site. Catheters remained in place until the patient was discharged from the Intensive Care Unit or profound pain relief was no longer needed. If soiling of the catheter site occurred, the catheter was removed.

\section{Results}

Thirty-one epidural catheters were placed in 30 infants via the caudal route over a nine-month period (Table). The catheters were inserted with ease by anaesthesia residents with various levels of expertise. Postoperative radiographs showed the catheter tip within one segment of the desired thoracic or lumbar level, that of skin incision, and our range of catheter tip placement was $L_{2}-T_{6}$. Two catheters, 22- and 24-ga, kinked and made reinjection impossible. This problem was not encountered with larger catheters. A third catheter had blood present when aspirated before reinjection. All three catheters were removed. There were no catheter-related complications at the time of insertion, or for a follow-up of 1 to 18 months postoperatively. All patients bad adequate analgesia with epidural morphine $0.05 \mathrm{mg} \cdot \mathrm{kg}^{-1}$. Dosing intervals ranged from $6-36 \mathrm{hr}$ (mean $15 \mathrm{hr}$ ). Catheters remained in place for an average of $46 \mathrm{hr}$ (range 18-96 hr). No episodes of nausea, vomiting, hypotension or skin rash were noted. Two infants required crede of the bladder for the period of epidural narcotic administration due to urinary retention.

One infant had an apnoeic episode three hours after injection of epidural morphine. This was treated immedi- 
TABLE Epidural morphine in infants

\begin{tabular}{|c|c|c|c|c|c|c|c|c|}
\hline Patient & Age (mo) & Weight (kg) & Conditioniprocedure & $\begin{array}{l}\text { Cath } \\
\text { size }(g a)\end{array}$ & $\begin{array}{l}\text { Cath } \\
\text { position }\end{array}$ & $\begin{array}{l}\text { Cath } \\
\text { duration (hr) }\end{array}$ & Comments & $\begin{array}{l}\text { No. of } \\
\text { doses }\end{array}$ \\
\hline $\mathbf{I}$ & 2.5 & 3.9 & GER/Nissen & 22 & $T_{10}$ & 68 & $\begin{array}{l}\text { Cath kinked } \\
\text { replaced } 12 \mathrm{hr} \\
\text { postoperatively }\end{array}$ & 5 \\
\hline 2 & 10 & 6.9 & GER/Nissen pyloroplasty & 22 & $T_{11}$ & 48 & & 3 \\
\hline 3 & 11 & 7.0 & RPS/Prosthesis thoractomy & 22 & $\mathrm{~L}_{1}$ & 67 & & 3 \\
\hline 4 & 7 & 9.2 & Nephrectomy, partial & 22 & $L_{1}$ & 24 & & 2 \\
\hline 5 & 5 & 5.1 & Rep. diaph. hernia & 20 & $T_{10}$ & 36 & & 4 \\
\hline 6 & 1 & 3.0 & GER/Nissen & 22 & $\mathrm{~L}_{1}$ & 48 & & 3 \\
\hline 7 & 13 & 5.1 & $\begin{array}{l}\text { Pharyngeal incoordination' } \\
\text { Nissen }\end{array}$ & 20 & $\begin{array}{l}\text { Not } \\
\text { known }\end{array}$ & 24 & & 3 \\
\hline 8 & 17 & 11 & Pyeloplasty & 20 & $\mathrm{~T}_{12}$ & 24 & & 2 \\
\hline 9 & 11.5 & 7.2 & SBO & 20 & $\mathrm{~L}_{1}$ & 46 & & 3 \\
\hline 10 & 4 & 5.2 & Colostomy closure & 22 & $\mathrm{~T}_{10}$ & 72 & & 4 \\
\hline 11 & 4.5 & 5.1 & SBO/NEC & 20 & $T_{10}$ & 72 & & 4 \\
\hline 12 & 13 & 7.9 & $\mathrm{SBO} /$ Nissen & 24 & $\mathrm{~T}_{10}$ & 24 & $\begin{array}{l}\text { Cath kinked } \\
\text { removed }\end{array}$ & 3 \\
\hline 13 & 1.5 & 3.1 & $\mathrm{SBO} / \mathrm{NEC}$ & 22 & $\mathrm{~L}_{2}$ & 96 & & 4 \\
\hline 14 & 5 & 5.4 & Colostomy & 22 & $\mathrm{~T}_{10}$ & 52 & & 5 \\
\hline 15 & 2 day & 3.2 & $\begin{array}{l}\text { Duodenal atresia/ } \\
\text { Pierre Robin anomaly }\end{array}$ & 22 & $\mathrm{~T}_{8}$ & 26 & & 2 \\
\hline 16 & 14 & 8.2 & SBO/adhesions & 20 & $\mathbf{T}_{8}$ & 48 & & 4 \\
\hline 17 & 24 & 10.9 & GER/Nissen & 20 & $\mathrm{~T}_{8}$ & 22 & $\begin{array}{l}\text { Blood aspirated } \\
\text { from cath when } \\
\text { attempt to reinject }\end{array}$ & 2 \\
\hline 18 & 1 & 2.2 & PDA ligation VSD/ASD & 22 & $T_{6}$ & 40 & & 4 \\
\hline 19 & $3 w k$ & 3.4 & $\begin{array}{l}\text { PA band diaphragm plication } \\
\text { (VSD/ASD) interrupted arch }\end{array}$ & 20 & $\mathrm{~T}_{8}$ & 48 & & 6 \\
\hline 20 & 15 & 8.8 & SBO & 20 & $\mathrm{~T}_{10}$ & 66 & & 4 \\
\hline 21 & 1 day & 2.8 & TEF repair & 22 & $\mathrm{~T}_{8}$ & 24 & & 2 \\
\hline 22 & 22 days & 2.1 & $\begin{array}{l}\text { Annular pancreas/ } \\
\text { gastojejunostomy }\end{array}$ & 22 & $\mathrm{~T}_{10}$ & 36 & & 3 \\
\hline 23 & 18 & 12 & Ureteral implant & 20 & & 18 & & 2 \\
\hline 24 & 1 day & 1.9 & Duodenal atresia & 22 & $T_{10}$ & 50 & & 3 \\
\hline 25 & 1 & 1.4 & NEC/Ileostomy closure & 20 & $\mathrm{~T}_{12}$ & 72 & & 8 \\
\hline 26 & 2 days & 2.2 & NEC/Exp lap & 20 & $\mathrm{~L}_{2}$ & 72 & & 4 \\
\hline 27 & 8 & 9.2 & Release intussusception & 20 & $\mathrm{~T}_{8}$ & 36 & apneic episode & 2 \\
\hline 28 & 13 & 7 & Release intussusception & 20 & $\mathrm{~L}_{2}$ & 36 & & 5 \\
\hline 29 & 2 & 3.2 & GER/Nissen & 20 & $\mathbf{L}_{2}$ & 62 & & 5 \\
\hline 30 & 13 & 8.9 & Colostomy closure & 20 & $\mathbf{L}_{1}$ & 48 & & 4 \\
\hline
\end{tabular}

Abbreviations: GER - gastroesophageal reflux; RPS - right pneumonectomy syndrome; UPJ - ureteropelvic junction; SBO - small bowel obstruction; NEC - necrotizing enterocolitis; PDA - patent ductus arteriosus; TEF - tracheoesophageal fistula; VSD - ventricularseptal defect; ASD atrial septal defect.

ately with intravenous naloxone and pulmonary ventilation with a bag and mask. The catheter level in this child was at $T_{8}$. The child had received $2 \mu \mathrm{g} \cdot \mathrm{kg}^{-1} \mathrm{IV}$ fentanyl intraoperatively $30 \mathrm{~min}$ before morphine administration. There was no evidence of incorrect dosage, subarachnoid infusion, or intravenous injection. This infant received one subsequent dose of local anaesthetic through the same catheter with no further problems.

\section{Discussion}

Postoperative pain relief using epidural narcotics is advantageous in the paediatric patient because it encour- ages a more rapid return of appetite and earlier ambulation. ${ }^{3}$ In neonates, adequate postoperative analgesia promotes more rapid weaning from the ventilator, and also decreases the level of circulating stress hormones, thus reducing time spent in the catabolic state; ${ }^{12}$ an advantage that may also be present when analgesia is provided through the epidural route.

Advantages of the caudally placed epidural catheter in comparison with the lumbar or thoracic approach include ease of insertion and reduced risk of dural puncture and spinal cord damage. Compared with single injection caudal block, lumbar or thoracic placement of the catheter 
permits use of a smaller volume of local anaesthetic, and allows access to the epidural space for continued analgesia postoperatively. The analgesia achieved with this technique using preservative-free morphine (Duramorph ${ }^{\circledR}$ ) $0.05 \mathrm{mg} \cdot \mathrm{kg}^{-1}$ was excellent and no catheter-related complications were encountered. One apnoeic episode out of 108 injections of morphine in 30 patients supports cardiorespiratory monitoring of these patients in an area where rapid response by nursing personnel can be expected if this complication occurs. One explanation of the episode could have been synergism between intraoperative fentanyl administration and the duramorph given $30 \mathrm{~min}$ after surgery was completed. Another possibility is that the dose of morphine may need to be reduced for higher levels of the catheter placement, because of the tendency of morphine to spread cephalad once it has crossed the dura. Epidural fentanyl, $1 \mu \mathrm{g} \cdot \mathrm{kg}^{-1}$ followed by an infusion at $1 \mu \mathrm{g} \cdot \mathrm{kg}^{-1} \cdot \mathrm{hr}^{-1}$ (concentration: $10 \mu \mathrm{g} \cdot \mathrm{ml}$ ) may provide a better alternative to morphine, since it is more lipophillic and less likely to have cephalad spread.

In conclusion, lumbar and thoracic epidural catheters can be placed using the caudal approach with little difficulty, and consistently within one segment of the desired interspace. We have experienced no catheterrelated complications while the catheter was in place or after removal. The catheters proved valuable for postoperative pain relief allowing adequate analgesia in all cases. One patient experienced an apnoeic episode three hours after epidural morphine injection. Consequently, we restrict epidural narcotics in children less than two years of age to those who will receive intensive care unit monitoring postoperatively.

\section{References}

1 Melman E, Penuelas A. Marrufo E. Regional anaesthesia in children. Anesth Analg 1975; 54: 387-9.

2 Rosen $K R$, Rosen DA. Caudal epidural morphine for control of pain after open heart surgery in children. Anesthesiology 1989; 70: 418-21.

3 Jensen $B H$. Caudal block for postoperative pain relief in children after genital operations. A comparison of bupivacaine and morphine. Acta Anaesthesiol Scand 1981; 25: 373-5.

4 Meignier M, Souron R, Le Neel JC. Postoperative dorsal epidural analgesia in the child with respiratory disabilities. Anesthesiology 1983; 59: 473-5.
5 Fell D, Derrington MC, Taylor E, Wandless JG. Paediatric postoperative analgesia. Anacsthesia 1988; 43: 107-10.

6 Soliman MG, Ansara $S$, Laberge $R$. Caudal anaesthesia in paediatric patients. Can Anaesth Soc J 1978; 25: 226-30.

7 Ecoffey $C$, Dubousset $A M$, Samii $K$. Lumbar and thoracic epidural anesthesia for urologic and upper abdomen surgery in infants and children. Ancsthesiology 1986; 65: 87-90.

8 Shapiro LA, Kedeikin MB, Shalev D, Hoffman S. Epidural morphine analgesia in children. Anesthesiology 1984; 61: 210-2.

9 Krane EJ, Jacobson LE, Lynn AM, Parion C, Tyler $D C$. Caudal morphine for postoperative analgesia in children - a comparison with caudal bupivacaine and intravenous morphine. Anesth Analg 1987; 66: 647-53.

10 Bosenberg AT, Bland AR, Schulte-Steinberg $O$, Downing $J W$. Thoracic epidural anesthesia via caudal route in infants. Anesthesiology 1988; 69: 265-9.

11 Takasaki M, Dohi S, Kawabata Y et al. Dosage of lidocaine for caudal anesthesia in infants and children. Anesthesiology 1977; 47: 527.

12 Anand KJS, Aynsley-Green A. Metabolic and endocrine effects of surgical ligation of PDA in human preterm neonate: are there implications for further improvement of postoperative outcome? Modern Problems in Pacdiatrics 1985; 23: 143-57. 